\title{
A Quantitative Research for Improving Reading Comprehension of First Year Engineering Students of QUEST, Pakistan Through Metacognitive Strategies
}

\author{
Zaimuariffudin Shukri Nordin ${ }^{1}$, Mansoor Ahmed Channa ${ }^{2} \&$ Abdul Malik Abassi ${ }^{3}$ \\ ${ }^{1}$ Faculty of Cognitive Sciences \& Human Development, University Malaysia Sarawak, Malaysia \\ ${ }^{2}$ Quaid-e-Awam University of Engineering, Science, and Technology, Nawabshah, Pakistan \\ ${ }^{3}$ Sindh Madressatul Islam University, Karachi, Pakistan \\ Correspondence: Mansoor Ahmed Channa, Quaid-e-Awam University of Engineering, Science, and Technology, \\ Nawabshah, Pakistan. E-mail: mansoor.english@yahoo.com
}

Received: January 24, 2018 Accepted: March 3, 2018 Online Published: March 17, 2018

doi:10.5539/ijel.v8n4p73 URL: https://doi.org/10.5539/ijel.v8n4p73

\begin{abstract}
This quantitative research investigates first year engineering students' reading comprehension using the different metacognitive strategies and scaffolding strategies. The research was undertaken at QUEST, Nawabshah, Pakistan. The respondents of this research were taken from four engineering departments including Mechanical Engineering, Energy and Environmental Engineering, Electrical Engineering, and Computer System Engineering A set of questionnaire was used among 311 respondents. The data was analyzed using descriptive statistics to analyze research variables through SPSS 17 for producing the Percentages, Mean and Standard Deviation of the data. The results acquired from data suggested that the engineering respondents used their metacognitive strategies in order to make their comprehension easy to apprehend the meaning of reading passages. This research also revealed the average uses of twenty important categories on metacognitive strategies as reported by engineering respondents. The mean score for 'I often find that I have been reading for class but don't know what it is all about' category $(M=2.65)$ was rated by the respondents of this research as the highest; while the mean score for 'reading instructions carefully before beginning a task' $(M=1.54)$ was rated as the lowest. The results also showed that the respondents of this study revealed the average uses of the twelve important categories of scaffolding. However, the mean score for 'When studying this course I often set aside time to discuss the course material with a group of students from the class' category $(M=2.29)$ was the highest for all respondents; whereas, the mean score for 'I ask teachers/students for help when they do not understand' $(M=1.37)$ was the lowermost. However, no category of metacognitive strategies and scaffolding fell into low level of usage. To sum up, results are presented for developing effective reading strategies for engineering students to improve their reading proficiency.
\end{abstract}

Keywords: metacognitive strategies, reading comprehension, scaffolding, reading strategies

\section{Introduction}

Reading comprehension is very important skill for engineering students to ensure success in their personal and professional life. Reading is considered as an active process involving readers to perceive correct meaning of the reading materials. A number of researchers have asserted the importance of English in engineering education (Pritchard \& Nasr, 2004; Venkatraman \& Premak, 2007). English is considered as the most important international language for science students possibly to gain professional knowledge in the course of reading texts in English (Pritchard \& Nasr, 2004). Joesba \& Ardeo (2005) stressed that engineering students should be equipped with specific English skills, which will become valuable resources in their career; therefore, English reading comprehension ability is crucial in academic settings and their future career for engineering students. According to Mudray (2006), it is essential for engineering students to read in English fluently to absorb fundamental knowledge from textbooks and deepen professional knowledge at their workplace. However, there are still a considerable number of engineering students struggling with reading in English (Ward, 2009). Some researchers have attributed engineering students' reading difficulty to vocabulary knowledge and proposed lexical instruction (Mudray, 2006; Ward, 2009). Further, Alderson (2000) informed that the knowledge of 
syntactic structure plays a significant role in L2 reading. Similarly, the research has demonstrated the relative contribution of syntactic knowledge to L2 reading comprehension performance (Shiotsu \& Weir, 2007). Further, Chang (2007) proposed a framework integrating cumulative sentence analysis (CSA) instruction to facilitate engineering students' comprehension of reading professional texts related to their own field. Canapero (2004) pointed out that students should be taught to read specific materials correctly using technical tools; the students should be familiar with technology to be used for learning independently using technical terms. However, Pritchard \& Nasr (2004) informed that teachers also should use technology tools at the time of teaching in class for developing students' comprehension and retention of knowledge.

A large body of literature has identified points of convergence between mathematical problem solving and comprehension strategies, and between scientific inquiry and comprehension strategies, but fewer studies have addressed comprehension strategies in the context of engineering. Many studies related to reading instruction in engineering (Cunningham, 2015) have emphasized text selection. The study concluded that certain types of children's literature based on fictional texts with problems that can be solved through engineering by providing a context rich, high-interest platform from which students can begin to engage in engineering design. McCormick \& Hammer (2014) and McCormick \& Hynes (2012) argued that children's literature can provide students with using complex structured engineering challenges. Their close analyses of students' discussion of literature illustrated that was used in complex forms of engineering design thinking through framing a problem and identifying implicit constraints, as they sought to solve fictional characters' problems. Rogers et al. (2014) and Tank, Moore, \& Pettis (2013) found that students comprehended challenging texts when they knew that they would design solutions for the characters. Researchers (Lacivita, 2006; Loveland, 2014; Wilson-Lopez \& Gregory, 2015) outlined, integrated with engineering design and asserted that the application of comprehension strategies can support students' comprehension of relevant information in textbooks.

\section{Reading Proficiency}

Reading proficiency can better be known with Chall's (1983) five stages of reading development which can be considered as the way to the advanced level of reading proficiency. Birch (2007) considered these five stages as the best model to portray the broad-spectrum developmental steps of "learning to read". In the present research, this theory can be used to help in terms of understanding the levels of reading proficiency of engineering students in Pakistan. These stages are initial reading, confirmation and fluency reading, reading to learn knowledge, multiple viewpoints, and construction and reconstruction. Chall (1983) described that stages 1 and 2 are regarded to the stage where readers start to learn written words through phonological knowledge, the abstract association of sound with word meaning, recognizing high frequency words and basic language patterns. Stage 2 indicates that good readers can decode written language more fluently as compared to the poor readers who lack adequate practice and in results frequently become failure to practice reading. Reading skills at this stage mainly focus on language decoding. Stage 3 of reading proficiency reveals about the interactive reading process where readers find a turning point in their reading development where readers begin "reading to learn" by developing ideas and gaining new information out of the printed language. These readers learn to skim and scan in order to find requisite information in a proficient manner. These readers use their prior knowledge to help their comprehension but remain limited in vocabulary size, cognitive ability, and personal experience; therefore, they need a lot of reading practice to increase vocabulary and prior knowledge. Further, stage 4 indicates that readers begin to read longer texts in which different facts and opinions are expressed perfectly and fluently by enabling readers to read in a top-down way. In stage 5 readers begin to read in a constructive way at university level with great confident by choosing text what they need to read by incorporating new knowledge to their own information. The reading proficiency at this stage includes reading strategies like evaluating critically, making inferences, and integrating segmented information through several foundations. Chall's (1983) theory explains in depth the complexity and the sequences of reading proficiency in terms of the interconnection between bottom-up and top-down strategies by fulfilling the shift from "learning to read" to "reading to learn". This theory not only did focus on L1 English reading but it can also be used for L2 reading proficiency (Grabe, 2009). It can be argued here that Chall's (1983) theory of reading development helps to examine engineering students' reading proficiency. This is most likely to be the case in this study. Even though engineering students are studying at an advanced level, their inadequate practice of English reading reveals that their language processing ability may still be at an early stage of reading development.

\section{Reading Comprehension in Pakistan}

According to Hudson (2007) reading appears to be at least as magic as pulling rabbits from hats, conjuring pigeons from coat sleeves, or producing dimes from behind someone's ear. Similarly, Grabe (2009) argues that the nature of reading when explored would seem more complex. Further, Alderson (2000) speculates that a clear 
definition of reading is yet to be agreed; however, all aspects of reading are important, but will not be brought together into a coherent and comprehensive account. Smith (2004) defined reading as a creative and constructive activity based on four characteristics: it is purposeful; it is selective; it is anticipatory, and it is based on comprehension of readers to have complete control. Grabe's (2009) reader purpose concept indicates about the intertwined relationship between reading purposes and the corresponding cognitive processes which contends that cognitive processes during reading are largely determined by differing reading purposes and each purpose requires a different combination of cognitive processes which can be grouped collectively as rapid, efficient, comprehending, interactive, strategic, flexible, purposeful, evaluative, learning, and linguistic.

Bibi (2009) investigated on how to improve the teaching of Reading Comprehension (RC) in Pakistani context. Qualitative approach using collaborative action research within the cyclic process of observe, reflect, act, and plan was used to study the situation. One English language teacher from a public school was exposed to different Reading Comprehension strategies like, pre-reading and post-reading activities such as guessing, predicting, skimming, scanning, vocabulary, and comprehension questions. Data were collected through reflective journals, pre-intervention and post-intervention, interviews, informal discussions, classroom observations, and field notes. In addition; four randomly selected students' works from the teacher's class were collected to look at the effectiveness of teaching from perspective of students' learning. The study revealed that the teacher was using GTM method without engaging students in Reading Comprehension process through different Reading Strategies (RS) such as predicting, guessing, skimming, and scanning. The action helped the teachers to improve Teaching of Reading Comprehension (TRC); was able to develop lesson plans, learnt to implement the new strategies and to some extent improved reflective practices. Similarly, the action enhanced students' RC, developed motivation and interest and helped to deeply understand the problem from different dimensions; interconnectivity of different factors like, system of examination, family background of the students', school's context, etc., relating to the TRC process while working in the natural environment and inform the policy management. The findings of the study imply in order to improve the TRC in EFL context of teachers' critical engagement in different professional programs inside and outside the school is necessary. Asif, Ghani, \& Shahid-ullahQuerish (2016) investigated the impact of nativization or indigenization of the text on the reading comprehension of ESL learners. The study is delimited to find out the effect of nativized and indigenized material on the reading comprehension of ESL learners at District Dera Ghazi Khan. Experimental research design was adopted to measure the effect of independent variable (Indigenized or nativized text) on the dependant variable (reading comprehension). After the selection of three short stories from 1stYear English Textbook taught in Pakistan, a sample based on two groups was formed from the given population. One group (Original or Controlled group) was taught from stories given in First year English textbooks. While another group (nativized or experimental group) was taught from the stories which were nativized or indigenized according to the models adopted by Alptekin, Erten and Karakas as well as Erten and Razi by replacing some textual and contextual cues of the original stories to the textual and contextual cues from Pakistani culture. To ascertain the impact of indigenized text on the reading comprehension, an MCQ based test was conducted and administered to both the groups. The results showed a positive effect of the indigenized or nativized stories on the reading comprehension of ESL learners of Dera Ghazi Khan.

Qanwal \& Karim (2014) explored correlation between reading strategies instruction and proficiency in text comprehension. The task is carried out by investigating the current practices of teaching and learning of L2 reading comprehension skills of the higher level L2 learners of English in Pakistan. In this regard, initially, the extent to which teachers incorporate reading strategies instruction into their teaching of ESL reading skills is analyzed; and students' proficiency in L2 text comprehension is evaluated. Subsequently, correlation between the two variables is identified by applying Pearson product-moment correlation test on the statistical scores attained for each variable. The research has employed both quantitative and qualitative measures for data collection and analysis. The research instruments include a questionnaire for students pertaining to the availability of reading strategy instruction, and a reading comprehension test. The results acquired through the collected data and their statistical analyses have highlighted a strong positive correlation between reading strategies instruction and learners' proficiency in text comprehension. Saleem \& Azam (2015) conducted study to examine the effectiveness of socio-cultural approach in reading comprehension skills. This is a novel approach for Pakistani teachers as it has not yet been tried in teaching especially in reading comprehension skills. To carry out this research, semi experimental research design was employed including pre-and post tests. Keeping in mind the nature of the data, it was analyzed quantitatively and interpreted qualitatively i.e. summary method. The findings of the study clearly exhibited that socio-cultural approach is quite effective for teaching reading comprehension skills. The independent sample t-tests were conducted both for pre-and post tests which strikingly show the difference of collaborative language learning approach. The results of this research suggest the use of more social and supportive methods in the perspective of language learning and teaching. It is more in support of a collaborative 
learning atmosphere which requires the presences of a professional or expert-peer that provides students with possibilities to correct themselves and simultaneously to understand the ideal procedures required for the learning of new and challenging abilities.

Iqbal, Mehwish, Fakharh, \& Bahram's (2015) study showed the factors responsible for poor English reading comprehension at secondary school level students. The purpose of this study is to explore those factors and to suggest remedies how to strengthen English reading comprehension of the students. English is the second language of Pakistani students and Kachru (1996) places it in the outer circle. Test and interviews are conducted to get the data. Different factors like poor command of vocabulary, habit of cramming, no interest to learn creativity in reading but the sole goal is just to pass the examination which are found responsible for poor English reading comprehension. Motivation to learn reading can develop reading comprehension skill of students. Khan (2011) investigated and reported the reading assessment practices of secondary school teachers to ascertain EFL/ESL learners' English reading performance at the secondary school level in Pakistan. This exploratory study was designed primarily to examine what specific reading assessment technique is preferred and brought into practice by secondary school teachers in an assessment of grade 10 students' reading comprehension. Keeping in view the aforesaid issue, the study was conducted in one urban district of Pakistan's densely populated city Karachi. To do so, samples were gathered from three different groups of teachers as private boys, girls, and coeducational schools. In this exploratory study, $(\mathrm{N}=120)$ teachers who were affiliated by different private non elitist schools had participated. The survey instrument was developed based on the suggested methods and assessment techniques for reading comprehension by Alderson (2000). The results yielded from data were analyzed and reported through mean, rank order and percentage study. The primary findings revealed and indicated that "multiple-choice" is considered at the top and most generally practiced followed by "short answer", "close-ended", and "subjective method" of reading assessment techniques among secondary school teachers.

\section{Schemata in Reading Comprehension}

The interactive model theory focuses on the attention on "schemata" referring to the foundation data of the reader in connection to his/her societal idea and also the substance of the content to be perused. A reader's understanding of the content will depend on his previous schema. Nonetheless, if the substance of content does not adjust to his schemata, the impact will prompt false impression of the data or a radical correction of his schemata in similarity with the reading content. The substance schemata and the formal schemata are thought to be the two sorts of schemata. Content schemata allude to learning that has been at one time put away about the context oriented data of the content. The right to gain entrance of substance schemata is thought to be significant to reading cognizance in spite of the way that few reading methodology systems may even now be utilized for ideal perception of the connection of the content (Sparks \& Ganschow, 2001). Haberlandt (1997) even underpinned this theory that readers don't simply gain understanding of the content all of a sudden; rather, viable perception is gained through important information and data from the text, the more open this learning and data is generally exhibited in the content, the simpler it is for the reader to completely fathom and comprehend what he/she is consistently perused. This is genuine particularly when the reader is acquainted with the introduced displayed foundation learning of the content. It is even expressed in various studies that both first dialect readers and second dialect readers, who have an expansive recognition with the relevant content as exhibited, can without much of a stretch review and comprehend the substance of the content contrasted with the individuals who have less foundation learning on the subject (Alderson, 1984). Carrell (1987) substantiates this by expressing that formal pattern alludes to the available information about the structure of the substance of the content which may be in manifestations of different reading articles. Studies performed on L1 and L2 reading demonstrate the readers who make utilization of formal schemata have higher learning and reading capacities contrasted with the individuals who don't do so (Carrell, 1988). Additionally, readers have the capacity review content data from a structure system that they have been habitually utilizing. An intensive preparing in the examination and distinguish of content structures on the sum and state of the data reviewed permit L2 readers expert successful method for perception (Raymond, 1993). The researchers conducted this study with the aims to improve the first year students' reading comprehension using metacognitive strategy.

\section{Research Methodology}

In this study, questionnaire was used to collect data from first year engineering students and teachers in QUEST, Pakistan. This survey questionnaire was partially constructed by the researcher and partially was adopted from Fauzan (2003) on the use of metacognitive strategies and scaffolding using five Likert scale. The questionnaire was checked by three experts in the field at faculty of Cognitive Sciences and Human Development, UNIMAS, Malaysia and was piloted at QUEST, Nawabshah before undertaking it in actual study. The results of the pilot study were reported to the supervisor who permitted to undertake the actual study in order to measure the 
reliability and validity of the questionnaire. The total 311 questionnaires were returned back out of 400 questionnaires. The researcher distributed questionnaires himself.

\section{Analysis of the Data and Research Findings}

Questionnaire data was analyzed through the Statistical Package for Social Sciences (SPSS) version 17. Descriptive statistics were used to analyze research variables for producing the Percentages, Mean and Standard Deviation of the data.

\subsection{Metacognitive Strategies Employed by Engineering Students}

To answer the questions 2 and 3, the respondents' responses from the 311 returned questionnaires about the metacognitive strategies used by engineering students are presented in the following table 6.4 based on the twenty categories involving metacognitions for reading and comprehension.

Table 1. Frequency of metacognitive strategies used by engineering respondents $(\mathrm{N}=311)$

\begin{tabular}{|c|c|c|c|c|c|c|c|}
\hline & & $\begin{array}{l}\text { Metacognitive } \\
\text { Strategies }\end{array}$ & & & & & \\
\hline & $\begin{array}{l}\text { A very Strong } \\
\text { Strategy }\end{array}$ & Strong Strategy & Simple Strategy & Rare Strategy & $\begin{array}{l}\text { Least } \\
\text { Strategy }\end{array}$ & $M$ & $S D$ \\
\hline $\begin{array}{l}\text { When reading a passage, I make up } \\
\text { questions to help focus my reading }\end{array}$ & 40.2 & 49.8 & 8.4 & 1.6 & 0.00 & 1.7299 & .74771 \\
\hline $\begin{array}{l}\text { When I become confused about } \\
\text { something I'm reading, I go back and try } \\
\text { to figure it out }\end{array}$ & 51.4 & 37.3 & 11.3 & 0.00 & 0.00 & 1.5981 & .68335 \\
\hline Having specific purpose for each strategy & 24.1 & 49.8 & 19.6 & 3.2 & 3.2 & 2.1158 & .91903 \\
\hline $\begin{array}{l}\text { Using different strategy for each text } \\
\text { depending on the situation }\end{array}$ & 37.0 & 35.4 & 19.6 & 8.0 & 0.00 & 1.9871 & .94348 \\
\hline $\begin{array}{l}\text { If the materials are difficult to understand, } \\
\text { I change the strategy/way I read the } \\
\text { materials }\end{array}$ & 42.4 & 36.7 & 12.9 & 4.8 & 3.2 & 1.8971 & 1.01395 \\
\hline $\begin{array}{l}\text { Before I begin studying I think about the } \\
\text { things I will need to do to learn }\end{array}$ & 36.7 & 30.9 & 26.0 & 6.4 & 0.00 & 2.0225 & .94159 \\
\hline $\begin{array}{l}\text { Thinking of several ways to solve a } \\
\text { problem }\end{array}$ & 45.3 & 34.7 & 11.9 & 4.8 & 3.2 & 1.8585 & 1.01881 \\
\hline $\begin{array}{l}\text { Reading instructions carefully before } \\
\text { beginning a task }\end{array}$ & 58.2 & 30.5 & 9.6 & 1.6 & 0.00 & 1.5466 & .73413 \\
\hline $\begin{array}{l}\text { Organizing time to accomplish reading } \\
\text { goals }\end{array}$ & 30.5 & 46.6 & 14.8 & 6.4 & 1.6 & 2.0193 & .92612 \\
\hline $\begin{array}{l}\text { Slowing down and focusing attention on } \\
\text { important information }\end{array}$ & 51.4 & 32.2 & 16.4 & 0.00 & 0.00 & 1.6495 & .74660 \\
\hline Focusing attention on the meaning & 45.3 & 40.8 & 12.2 & 1.6 & 0.00 & 1.7010 & .74312 \\
\hline $\begin{array}{l}\text { Drawing diagrams to understand difficult } \\
\text { text }\end{array}$ & 28.6 & 27.7 & 17.7 & 16.4 & 9.6 & 2.5080 & 1.31705 \\
\hline Translating information into own words & 51.1 & 29.3 & 13.2 & 3.2 & 3.2 & 1.7814 & 1.00824 \\
\hline Making connection of text to self & 35.4 & 37.0 & 16.4 & 6.4 & 4.8 & 2.0836 & 1.09813 \\
\hline Rethinking misconceptions & 33.8 & 45.0 & 14.8 & 4.8 & 1.6 & 1.9550 & .90762 \\
\hline $\begin{array}{l}\text { When studying for this course I try to } \\
\text { determine which concepts I don't } \\
\text { understand well }\end{array}$ & 44.1 & 37.9 & 16.4 & 1.6 & 0.00 & 1.7556 & .78170 \\
\hline $\begin{array}{l}\text { I often find that I have been reading for } \\
\text { class but don't know what it is all about }\end{array}$ & 22.5 & 28.6 & 19.6 & 19.6 & 9.6 & 2.6527 & 1.28577 \\
\hline $\begin{array}{l}\text { When I study, I set goals for myself in } \\
\text { order to direct my activities in each study } \\
\text { period }\end{array}$ & 35.7 & 39.9 & 14.5 & 6.8 & 3.2 & 2.0193 & 1.03157 \\
\hline $\begin{array}{l}\text { Reading with opposite meanings to form } \\
\text { an opinion }\end{array}$ & 22.2 & 34.1 & 21.2 & 9.6 & 12.9 & 2.5691 & 1.28799 \\
\hline $\begin{array}{l}\text { I try to change the way I study in order to } \\
\text { fit the subjects of course requirement and } \\
\text { instructor's teaching style }\end{array}$ & 41.8 & 35.4 & 11.6 & 9.6 & 1.6 & 1.9389 & 1.03150 \\
\hline
\end{tabular}


Table 1 revealed the average uses of the twenty important categories on metacognitive strategies were reported by 311 engineering respondents. The results showed that "a very Strong Strategy" used for metacognition was "reading instructions carefully before beginning a task" with $58.2 \%$ to improve reading and to elucidate the thorough knowledge about the text beginning with great care. The respondents rated reading instructions category as "a very strong strategy" to improve reading comprehension before starting any task on reading passages. This shows that reading instructions would be beneficial to begin any task to understand the plot of the texts. Similarly, the respondents rated "a very Strong Strategy" to the metacognitive category including "When I become confused about something I'm reading, I go back and try to figure it out" with $51.4 \%$ followed by another category like "Slowing down and focusing attention on important information" with same $51.4 \%$. This revealed that when the students became confused while reading, they read passages again or they read slowly and focused on the most important piece of text in the passage to know clear meaning of the text and perceive the proper information. These two strategies indicated that the readers may not ignore the texts when they find some difficulties due to difficult texts. They would enable if they would go back and start reading again slowly with great attention.

Further, the results showed that "translating information into own words" strategy was also considered as "a very Strong Strategy" having $51.1 \%$ by the respondents of this research to be used to develop reading comprehension. This strategy would enable engineering students to interconnect text into their own words by means of translating process. This strategy would be beneficial for engineering students to promote their reading knowledge with that of translating proficiency of certain text into their own words. Moreover, the respondents rated "when reading a passage, I make up questions to help focus my reading" with $49.8 \%$ as the "strong strategy" to be used to develop reading comprehension. The respondents asserted to make up questions to focus reading for developing reading proficiency. Similarly, the respondents considered "having specific purpose for each strategy" as the "strong strategy" rated with $49.8 \%$ to be used to enhance reading proficiency. This shows that without purposes, no development would be occurred; hence, these respondents asserted to have a particular reading aim for every metacognitive strategy. Further, the respondents rated "organizing time to accomplish reading goals" as the "strong strategy" with $46.6 \%$ asserting readers to form time undertake reading objectives. The results of this category suggest making certain reading schedule to develop comprehension proficiency.

Conversely, the other strategies including thinking of several ways to solve a problem, focusing attention on the meaning, rethinking misconceptions, if the materials are difficult to understand I change the strategy/way I read the materials, when studying for the course I try to determine which concepts I don't understand well, and I try to change the way I study in order to fit the subjects of course requirement and instructor's teaching style were rated by the respondents of this research either as "a very strong strategy" or "strong strategy" to develop reading comprehension for engineering students. However, the mean score for "I often find that I have been reading for class but don't know what it is all about" category $(M=2.65)$ for all respondents was the highest; while the mean score for "reading instructions carefully before beginning a task" category $(M=1.54)$ was the lowest. However, no category of metacognitive strategies fell into low level of practice.

\subsection{Results of Scaffolding}

To answer the question 5 of this present research, the respondents' reactions from the 311 returned questionnaires about the scaffolding used by engineering respondents are presented in the following table 2 based on the twelve categories involving teachers scaffolds and peer to peer scaffolds for reading comprehension. 
Table 2. Frequency of scaffolding used by engineering respondents $(\mathrm{N}=311)$

\begin{tabular}{|c|c|c|c|c|c|c|c|}
\hline & & Scaffolding & & & & & \\
\hline & $\begin{array}{l}\text { A Very strong } \\
\text { Scaffolding }\end{array}$ & $\begin{array}{l}\text { Strong } \\
\text { Scaffolding }\end{array}$ & $\begin{array}{l}\text { Moderate } \\
\text { Scaffolding }\end{array}$ & $\begin{array}{l}\text { Fair } \\
\text { Scaffolding }\end{array}$ & $\begin{array}{l}\text { Rare } \\
\text { Scaffolding }\end{array}$ & $M$ & $S D$ \\
\hline $\begin{array}{l}\text { I ask teachers/students for help when } \\
\text { they do not understand } \\
\text { I like students helping classmates to } \\
\text { choose text }\end{array}$ & 70.1 & 21.9 & 8.0 & 0.00 & 0.00 & 1.3794 & .63048 \\
\hline $\begin{array}{l}\text { I want my teachers/students finding } \\
\text { exact meaning }\end{array}$ & 32.2 & 35.0 & 28.0 & 4.8 & 0.00 & 2.0547 & .89094 \\
\hline $\begin{array}{l}\text { I change strategies when students do } \\
\text { not comprehend }\end{array}$ & 28.6 & 48.6 & 16.4 & 6.4 & 0.00 & 2.0064 & .84240 \\
\hline $\begin{array}{l}\text { I re-evaluate students' assumptions } \\
\text { when they get confused }\end{array}$ & 43.4 & 36.3 & 13.8 & 3.2 & 3.2 & 1.8650 & .98755 \\
\hline $\begin{array}{l}\text { I stop and go back over new } \\
\text { information that is not clear }\end{array}$ & 38.6 & 43.1 & 11.9 & 3.2 & 3.2 & 1.8939 & .95630 \\
\hline $\begin{array}{l}\text { I support my students in reading } \\
\text { difficult task }\end{array}$ & 47.9 & 33.8 & 14.8 & 3.5 & 0.00 & 1.7395 & .83840 \\
\hline $\begin{array}{l}\text { I like teaching critical activities in } \\
\text { reading for comprehension }\end{array}$ & 43.4 & 33.1 & 18.6 & 1.6 & 3.2 & 1.8810 & .98144 \\
\hline $\begin{array}{l}\text { I try to work with other students } \\
\text { from this class to complete the } \\
\text { course assignments }\end{array}$ & 30.9 & 35.4 & 20.9 & 12.9 & 0.00 & 2.1576 & 1.00528 \\
\hline $\begin{array}{l}\text { When studying this course, I often } \\
\text { set aside time to discuss the course } \\
\text { material with a group of students } \\
\text { from the class }\end{array}$ & 25.4 & 42.4 & 17.7 & 6.4 & 8.0 & 2.2926 & 1.15336 \\
\hline $\begin{array}{l}\text { I ask students/peers for critical } \\
\text { thinking and problem solving based } \\
\text { reading }\end{array}$ & 40.5 & 33.8 & 11.3 & 8.0 & 6.4 & 2.0611 & 1.19115 \\
\hline $\begin{array}{l}\text { when studying for this course, I } \\
\text { often try to explain the material to a } \\
\text { classmate or a friend }\end{array}$ & 46.9 & 38.3 & 11.6 & 1.6 & 1.6 & 1.7267 & .84961 \\
\hline
\end{tabular}

Table 2 revealed the average uses of the twelve important categories of scaffolding were reported by 311 engineering respondents. The results showed that the respondents of this study rated scaffolding category "I ask teachers/students for help when they do not understand" with highest $70.1 \%$ was considered as "a very strong scaffolding" as compared to other categories. This shows both teachers offered help to the students whereas students asked their teachers to help them at the time of their difficulty in reading and comprehension. This scaffolding category indicated that both teachers and students support to make passages comprehensible by clarifying deep meaning of the texts. Further, the respondents rated category "I like students helping classmates to choose text" as "strong scaffolding" having 53.4\%. This category proved in results that the respondents preferred their peers to help them in the selection of the texts for their reading. Selection of the text category would be beneficial for them to choose text according to the interest in order to develop their reading comprehension and this would possible through peer scaffolds or teacher scaffold through reading their practices. Similarly, the respondents of this study rated "I change strategies when students do not comprehend" as the third most important category of scaffolding having $48.6 \%$ and considered this as the "strong scaffolding" in this research. This showed that when students did not comprehend the texts in the passages, their teachers ultimately changed the reading strategies in order to clarify the meaning of the texts and to make them understand the texts easily. Sometimes, they themselves changes reading strategies and chose all those strategies which seemed simple for them to carry on their reading comprehension.

Moreover, engineering respondents rated "I support my peers/students in reading difficult task" as "a very strong scaffolding" category with $47.9 \%$. This indicated that the teachers always supported their students and taught them how to read and comprehend difficult passages of the texts; whereas, students helped their peers to handle difficult passages in terms of developing reading proficiency. This proved from the results that teachers support or peer support would be beneficial in terms of understanding the texts. Similarly, the category "when studying for this course, I often try to explain the material to a classmate or a friend" was rated by the respondents as "a 
very strong scaffolding" with $46.9 \%$ responses to focus on peer scaffolds for explaining passages in order to clarify certain meaning of the texts. Peer scaffolding was regarded as the important tool to collaborate in reading and understanding the exact meaning of the texts. Students' collaboration was shown through the results in terms of scaffolding category as reported by the engineering respondents. Additionally, the respondents rated two more scaffolding categories including "I re-evaluate students" assumptions when they get confused" and "I like teaching critical activities in reading for comprehension" as "a very strong scaffolding" having $43.4 \%$. Both categories indicated that the teachers supported their readers by teaching different critical activities in reading comprehension and helped them to re-evaluate them when they found difficulties in reading and comprehension. The results on these both categories also suggested that the teachers involved with students in terms of reading passages and taught them to re-evaluate their reading proficiency.

The results also indicate that the category "I stop and go back over new information that is not clear" was rated as "strong scaffolding" with $43.1 \%$ by the respondents of this research. This indicated that when students did not understand any text then they left it unread and turned towards new information to read and comprehend the text properly. This also showed that the students did not avoid reading but continued reading to perceive the meaning of the texts. Similarly, the results of category "when studying this course, I often set aside time to discuss the course material with a group of students from the class" indicated that the respondents rated this as the "strong scaffolding" with $42.4 \%$ by highlighting the importance of reading with collaboration of students to one another in order to comprehend properly. This category also has shown the vital importance of group reading for broader sense and for knowing the meaning of the texts in depth. In the same way, the results revealed that the category "I ask students/peers for critical thinking and problem solving based reading" was rated "a very strong scaffolding" with $40.5 \%$ to promote thinking critically among students to participate in problem solving based reading activities to enhance their comprehension proficiency. This category of scaffolding would enable readers to help peers to peers and teachers the students to take active part in the activity.

Conversely, the categories "I try to work with other students from this class to complete the course assignments" and "I want my teachers/students finding exact meaning" were rated by the respondents of this study as the "strong strategy" to improve reading ability for engineering students. However, the mean score for "When studying this course, I often set aside time to discuss the course material with a group of students from the class" category $(M=2.29)$ was the highest for all respondents; whereas the mean score for "I ask teachers/students for help when they do not understand" category $(M=1.37)$ was the lowermost. However, no category of scaffolding fell into low level of usage.

\section{Discussion and Summary of the Findings}

Engineering students at QUEST use metacognitive strategies only for carrying out their reading comprehension to accomplish their academic needs and to be prepared for their future reading texts and promote their understanding for their professions. Thus, the QUEST administration and Engineering teachers should arrange different reading comprehension courses on the basis of content related to the specific needs that were identified in this study. Self-questioning, vocabulary, summarizing, paraphrasing, and prior knowledge were rated as the most important strategies used for promoting reading proficiency. Therefore, reading comprehension courses based on metacognitive strategies for engineering students must be arranged based on rereading, grammar structure knowledge, increasing vocabulary, using prior experiences, and self-questioning as the top priority, ahead of summarizing and other strategies. Further, teachers should arrange compulsory and optional reading comprehension courses with objectives related to the engineering students and engineering programs. According to the results of this study, the teaching methodology should be based on students' use of metacognition in and out of class, having summer camps and problems focusing on modern content of reading texts. This present research indicated that the engineering students were completely attentive and knew about their reading comprehension strengths and weaknesses to regulate their thinking abilities at the time of reading texts of the passages. Many studies including (Pritchard \& Nasr, 2004; Qanwal \& Karim, 2014; Joesba \& Ardeo, 2005) used different strategies and considered as the most important for developing reading comprehension; the findings of present research match with the earlier studies. The results acquired from data suggested that the engineering respondents used their metacognitive strategies in order to make their comprehension easy to apprehend the meaning of reading passages. The results of this present research are reliable and consistent as compared with the results of past studies which asserted that the readers always used metacognitive strategies to help their reading comprehension to be enhanced; On the contrary, this present research approves the claims made in the past research (Alderson, 2000; Mudray, 2006; Shiotsu \& Weir, 2007; Ward, 2009) in terms of the strategies identified and used by the participants. This present study confirms metacognitive strategies for improving comprehension levels of engineering students. The results of the analysis of the data obtained from the questionnaires can be 
summarized as follows:

1) This research also revealed the average uses of twenty important categories on metacognitive strategies as reported by engineering respondents. The mean score for I often find that I have been reading for class but don't know what it is all about category $(M=2.65)$ was rated by the respondents of this research as the highest; while the mean score for reading instructions carefully before beginning a task $(M=1.54)$ was rated as the lowest. However, no category of metacognitive strategies fell into low level of practice.

2) The results also showed that the respondents of this study revealed the average uses of the twelve important categories of scaffolding. However, the mean score for "When studying this course I often set aside time to discuss the course material with a group of students from the class" category $(M=2.29)$ was the highest for all respondents; whereas the mean score for "I ask teachers/students for help when they do not understand" ( $M=$ 1.37) was the lowermost. However, no category of scaffolding fell into low level of usage.

\section{References}

Alderson, J. C. (1984). Reading in a foreign language: A reading problem or a language problem? In J. C. Alderson \& A. H. Urquhart (Eds.), Reading in a foreign language (pp.1-27). New York: Longman.

Alderson, J. C. (2000). Assessing reading. Cambridge: Cambridge University Press. https://doi.org/10.1017/CBO9780511732935

Asif, M., Ghani, M., \& Querish, S. (2016). Effect of nativized stories on the reading comprehension of Pakistani ESL learners at intermediate level. Sci.Int. (Lahore), 28(3), 3149-3155.

Bibi, H. (2009). Improving the teaching of reading comprehension in English as a foreign language classroom in Karachi (Unpublished master's dissertation). Aga Khan University, Karachi, Pakistan.

Birch, B. (2007). English L2 reading: Getting to the bottom (2nd ed.). Mahwah, NJ: Lawrence Erlbaum.

Canapero, M. (2004). Connecting, motivating and raising awareness via WELL: Developing e-learning environments for science students. ReCALL, 16, 330-344. https://doi.org/10.1017/S095834400400062X

Carrell, P. L. (1987). Content and formal schemata in ESL reading. TESOL Quarterly, 21(3), 461-481. https://doi.org/10.2307/3586498

Carrell, P. L. (1988). Introduction: Interactive approaches to second language reading. In P. L. Carrell, J. Devine, \& D. E. Eskey (Eds.), Interactive approaches to second language reading (pp. 1-7). Cambridge: CUP. https://doi.org/10.1017/CBO9781139524513.003

Chall, J. S. (1983). Stages of reading development. New York, NY: McGraw-Hill.

Chang Y. K. (2007). English for science and technology. Taipei, Taiwan: New Wun Ching Developmental Publishing.

Cunningham, C. (2015). Engineering is elementary: Engineering for elementary school students. In C. I. Sneider (Ed.), The go-to guide for engineering curricula, pre-K-5: Choosing and using the best instructional materials for your schools (pp. 19-38). Thousand Oaks, CA: Corwin.

Fauzan, N. (2003). The effects of metacognitive strategies on reading comprehension: A quantitative synthesis and the empirical investigation. Durham theses, Durham University. Retrieved from http://etheses.dur.ac.uk/1086/

Grabe, W. (2009). Reading in a second language. New York: Cambridge University Press.

Haberlandt, K. (1997). Cognitive psychology (2nd ed.). Boston: Allyn \& Bacon.

Hudson, T. (2007). Teaching second language reading. Oxford, England: Oxford University Press.

Iqbal, M., Mehwish, N., Fakharh, M., \& Bahram, K. (2015). Factors Responsible for Poor English Reading Comprehension at Secondary Level. Communication and Linguistics Studies, l(1), 1-6.

Joesba, M., \& Ardeo, G. (2005). Student engineers, ESP courses, and testing with cloze tests. ESP World, 2(10). Retrieved from http://www.esp-world.info/contents.htm

Kachru, B. B. (1996). World English: Agony and Ecstasy. Journal of Aesthetic Education, 30(2), 135-155. https://doi.org/10.2307/3333196

Khan, I. (2011). Reading assessment techniques among selected secondary school teachers in Pakistan: current trends and practices. International Journal on New Trends in Education and Their Implications, 2(4), 58-75.

Lacivita, B. (2006). Integrating reading in a technical curriculum. Technology Association of Pennsylvania 
Journal, 54(4), 12-13.

Loveland, T. (2014). Incorporating disciplinary literacy in technology and engineering education. Technology and Engineering Teacher, 74(3), 8-13.

McCormick, M., \& Hammer, D. (2014). The beginnings of engineering design in an integrated engineering and literacy task. In J. L. Polman (Eds.), Learning and becoming in practice: The International Conference of the Learning Sciences (Vol. 2, pp. 633-640). Boulder, CO: International Conference of the Learning Sciences. http://www.isls.org/icls2014/downloads/ICLS\%202014\%20Volume\%202\%20\%28PDF\%29-Cover.pdf

McCormick, M., \& Hynes, M. M. (2012). Engineering in a fictional world: Early findings from integrating engineering and literacy. Conference Proceedings of the American Society for Engineering Education, San Antonio, TX.

Mudray, O. (2006). Engineering English: A lexical frequency instructional model. English for Specific Purposes, 25(2), 235-256. https://doi.org/10.1016/j.esp.2005.05.002

Pritchard, R. M. O., \& Nasr, A. (2004). Improving reading performance among Egyptian engineering students: Principles and practice. English for Specific Purposes, 23(4), 425-445. https://doi.org/10.1016/j.esp.2004.01.002

Qanwal, S., \& Karim, S. (2014). Identifying correlation between reading strategies instruction and 12 text comprehension. Journal of Language Teaching and Research, 5(5), 1019-1032. https://doi.org/10.4304/jltr.5.5.1019-1032

Raymond, M. (1993).The effects of structure strategy training on the recall of expository prose for university students reading French as a second language. Modern Language Journal, 77(4), 445-458. https://doi.org/10.1111/j.1540-4781.1993.tb01992.x

Rogers, C. R., Hammer, D., Portsmore, M., Milto, E., Watkins, J., Spencer, K., \& Coppola, S. (2014). Novel engineering: Language arts standards and values. Retrieved from $\mathrm{http}: /$ novelengineering.org/novelengineering/why-novel- engineering/standards/

Saleem, T., \& Azam, S. (2015). The use of sociocultural approach for teaching esl reading skills to "o" level students in Pakistan. Journal of Literature, Languages and Linguistics, 5, 46-52.

Shiotsu, T., \& Weir, C. J. (2007). The relative significance of syntactic knowledge and vocabulary breadth in the prediction of reading comprehension test performance. Language Testing, 24, 99-128. https://doi.org/10.1177/0265532207071513

Smith, F. (2004). Understanding reading: A psycholinguistic analysis of reading and learning (6th ed.). Mahwah, NJ: Lawrence Erlbaum.

Sparks, R., \& Ganschow, L. (2001). Aptitude for learning a foreign language. Annual Review of Applied Linguistics, 21, 90-111. https://doi.org/10.1017/S026719050100006X

Tank, K. M., Moore, T. J., \& Pettis, C. (2013). The Picture STEM project: A curricular approach using picture books to transform STEM learning in elementary classrooms. Conference Proceedings of the American Society for Engineering Education. Atlanta, GA.

Venkatraman, G., \& Premak, P. (2007). English language skills for engineering students: A needs survey. ESP World, 3(16). Retrieved from http://www.esp-world.info/contents.htm

Ward, J. (2009). A basic engineering English word list for less proficient foundation engineering undergraduates. English for Specific Purposes, 28(3), 170-182. https://doi.org/10.1016/j.esp.2009.04.001

Wilson-Lopez, A., \& Gregory, S. (2015). Fostering engineering design thinking through literacy instruction for elementary students. Paper presented at the annual meeting of the American Educational Research Association, Chicago, IL.

\section{Copyrights}

Copyright for this article is retained by the author(s), with first publication rights granted to the journal.

This is an open-access article distributed under the terms and conditions of the Creative Commons Attribution license (http://creativecommons.org/licenses/by/4.0/). 